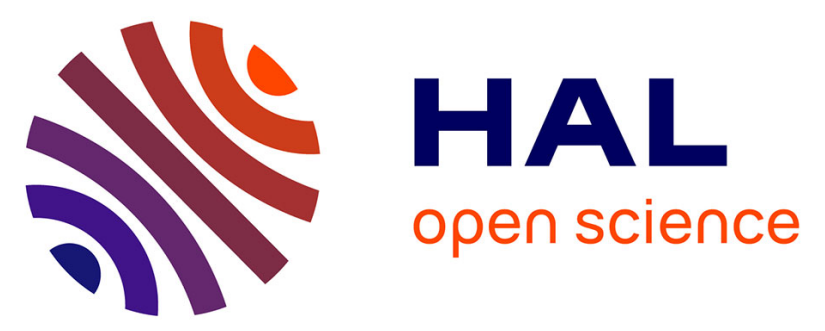

\title{
Increased risk of HIV-infection among school-attending orphans in rural Zimbabwe
}

\author{
Sophie Pascoe, Lisa Langhaug, Jeffrey Durawo, Godfrey Woelk, Rashida \\ Ferrand, Shabbar Jaffar, Richard Hayes, Frances Cowan
}

\section{- To cite this version:}

Sophie Pascoe, Lisa Langhaug, Jeffrey Durawo, Godfrey Woelk, Rashida Ferrand, et al.. Increased risk of HIV-infection among school-attending orphans in rural Zimbabwe. AIDS Care, 2010, 22 (02), pp.206-220. 10.1080/09540120903111528 . hal-00559604

\section{HAL Id: hal-00559604 https://hal.science/hal-00559604}

Submitted on 26 Jan 2011

HAL is a multi-disciplinary open access archive for the deposit and dissemination of scientific research documents, whether they are published or not. The documents may come from teaching and research institutions in France or abroad, or from public or private research centers.
L'archive ouverte pluridisciplinaire HAL, est destinée au dépôt et à la diffusion de documents scientifiques de niveau recherche, publiés ou non, émanant des établissements d'enseignement et de recherche français ou étrangers, des laboratoires publics ou privés. 

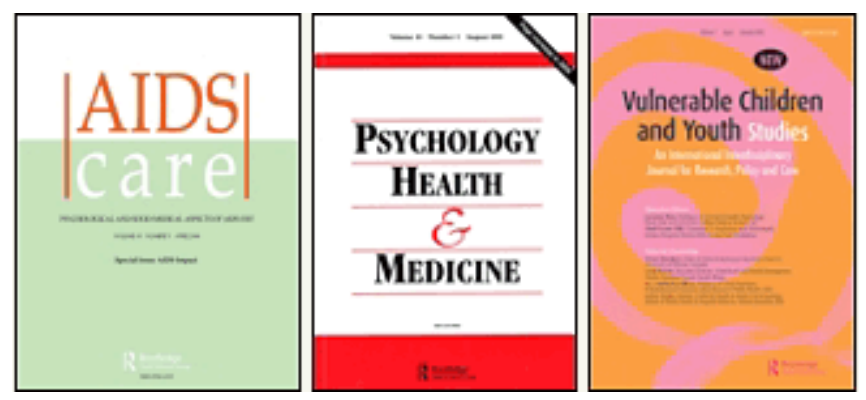

\section{Increased risk of HIV-infection among school-attending orphans in rural Zimbabwe}

\begin{tabular}{|r|l|}
\hline Journal: & $\begin{array}{l}\text { AIDS Care - Psychology, Health \& Medicine - Vulnerable Children } \\
\text { and Youth Studies }\end{array}$ \\
\hline Manuscript ID: & AC-2009-01-0011.R1 \\
\hline Journal Selection: & AIDS Care \\
\hline Keywords: & Zimbabwe, Youth, Orphan, Sexual behaviour, HIV/AIDS \\
\hline
\end{tabular}

\section{scholarONE \\ Manuscript Central}


Short title: HIV among school-attending orphans

Increased risk of HIV-infection among school-attending orphans in rural Zimbabwe 


\section{Abstract}

In Zimbabwe around 1.1 million children have been orphaned due AIDS. We conducted a survey among school-attending youth in rural South-Eastern Zimbabwe in 2003, and examined the association between orphaning and risk of HIV.

We enrolled 30 communities in three provinces. All students attending Year 2 of secondary school were eligible. Each completed a questionnaire and provided a finger-prick blood specimen for testing for HIV-1 and HSV-2 antibodies. Female participants were tested for pregnancy.

6791 participants were recruited ( $87 \%$ of eligible); $35 \%$ had lost one or both parents $(20 \%$ of participants had lost their father; $6 \%$ their mother; $9 \%$ both parents). Orphans were not poorer than non-orphans based on reported access to income, household structure, and ownership of assets. There was strong evidence that orphans, and particularly those that had lost both parents, were at increased sexual risk, being more likely to have experienced early sexual debut; to have been forced to have sex; and less likely to have used condoms. Fifty one students were HIV positive $(0.75 \%)$. Orphans were three times more likely to be HIV infected than non-orphans (adjusted odds ratio $=3.4 ; 95 \% \mathrm{Cl}: 1.8-6.6$ ). Over $60 \%$ of those HIV-positive were orphaned.

Among school-going youth, the rates of orphaning were very high; there was a strong association between orphaning and increased risk of HIV, and evidence of greater sexual risktaking among orphans. It is essential that we understand the mechanisms by which orphaned children are at increased risk of HIV in order to target prevention and support appropriately.

Keywords: HIV/AIDS, Zimbabwe, youth, orphan, sexual behaviour 


\section{Introduction}

A major consequence of the HIV/AIDS epidemic has been the rapid increase in the prevalence of orphanhood (Monasch \& Boerma, 2004), defined by the World Health Organization (WHO) as the loss of one or both parents. It is estimated that in subSaharan Africa, there are 12 million children aged 0-17 years orphaned due to AIDS and this is predicted to rise to 15.7 million by 2010 (UNICEF, 2006).

Despite global recognition of the magnitude and severity of the AIDS orphan issue, the relationship between orphaning and these children's' subsequent risk of HIV is complex, and the mechanisms are not clearly understood (Foster \& Williamson, 2000; Nyamukapa et al., 2008). A few studies have shown poorer school attendance, grade progression and poorer nutrition among orphans than non-orphans, but the current research does not provide a comprehensive picture of the problems faced by orphaned children in HIVendemic settings, or whether those orphans have an increased risk of acquiring HIV (Andrews, Skinner, \& Zuma, 2006; Parikh et al., 2007; UNICEF, 2006).

In Zimbabwe there are estimated to be 1.4 million orphans, almost $80 \%$ of whom have been orphaned as a result of AIDS (UNAIDS/WHO, 2008; UNICEF, 2006). The Zimbabwe Demographic Health Survey $2005-06$ estimated that $36 \%$ of children aged $15-17$ years old were orphaned, with rural children more likely to be orphaned than urban children (Central Statistical Office (CSO) [Zimbabwe] and Macro International Inc., 2007). This paper reports on data collected as part of the baseline survey for a community randomised trial of an adolescent HIV preventive intervention conducted in Zimbabwe in 2003 (Cowan et al., 2008). We examine the association between orphanhood and risk of HIV, and explore the factors associated with vulnerability to HIV infection in this group. 


\section{Methods}

\section{Study setting and population}

The study was conducted in 30 rural communities in three provinces (Manicaland, Mashonaland East and Masvingo) in south east Zimbabwe (see Figure 1). All adolescents enrolled in the second year at selected secondary schools within these communities were eligible to participate in the survey. Details around enrolment and recruitment of eligible individuals are described elsewhere (Cowan et al., 2008).

(Figure 1)

\section{Data collection and collection of biological specimens}

Each participant self-completed a questionnaire in Shona (the indigenous language). The questionnaire included questions on demographic factors, education, household, knowledge and attitudes related to HIV/AIDS, reported sexual behaviour, self-esteem, and socio-economic status (SES). The questionnaire took just over one hour to complete and was completed in a class-room setting, ensuring that each participant had sufficient space to keep their answers private. Given that all participants were in their second year of secondary school, all were able to complete the questionnaire unaided.

Each participant provided a dried blood spot sample (DBS) (US National Committee for Clinical Laboratory Standards, 1997). Samples were tested in the National Microbiology Reference Laboratory in Harare for HIV-1 and HSV-2 antibodies using validated testing algorithms described in detail elsewhere (Cowan et al., 2008; US Department of Health and Human Services, 2000). All girls were asked to provide a urine sample for pregnancy testing. 


\section{Statistical analyses}

Data were double entered and analyses were performed using STATA 10 (Stata Corp., College Station, Texas, USA). Orphan status was determined based on answers to the questions 'is your biological mother still alive?' and 'is your biological father still alive?'. Two orphanhood variables were created -1 ) participants were classified as orphans (lost one or both parents) and non-orphans (both parents alive); 2) orphans were further classified as paternal (lost father only), maternal (lost mother only) or double (lost both parents) orphans.

Univariate and multivariate analyses were performed using generalized estimating equations (GEE) with exchangeable correlation matrix and robust standard errors to account for the cluster sample design. Analyses were adjusted for age and province $a$ priori and stratified by gender.

The relationships between orphanhood and knowledge, self-esteem, self-efficacy, selfreported behaviour, and biomarkers for HIV and HSV-2 were assessed. Factors were considered significantly associated if Wald Chi-square test $p$-value was $<0.05$. Cox regression (with shared frailty to allow for the clustered design) and Kaplan-Meier estimates were used to explore the association between orphanhood and age of sexual debut. Multivariate analyses were performed to identify those factors which were independently associated (Wald chi-square $p<0.1$ ) with increased risk of HIV after adjusting for potential confounders. Records where these data were missing were excluded from the models.

\section{Ethics}

Ethical approval was obtained from the Medical Research Council of Zimbabwe and the ethics committees of University College London and the London School of Hygiene and Tropical Medicine. Participants were not given the results of their HIV or HSV-2 tests 
during the survey but were informed that free voluntary counselling and testing services would be provided by research staff at community clinics for any community members wishing to know their HIV status, throughout the four years that the trial was underway.

\section{Results}

\section{Recruitment and enrolment}

The survey was conducted between March and June 2003 prior to implementation of the trial intervention which was rolled out in study communities as the baseline survey was completed. In total 6791 participants ( $48 \%$ female) were recruited ( $87 \%$ of those eligible; $94 \%$ of those young people whose parents had consented to their participation) (Cowan et al., 2008). Gender data were available for 716 of the 1094 non-respondents, $41 \%$ of whom were female. There was no difference in the mean age of participants and nonrespondents $(n=590)$. For those who participated in the baseline survey, age ranged from 12-21 years; girls were younger than boys (mean age: boys 15.5yrs (Standard deviation (SD) 1.2) vs. girls 14.9yrs (SD 1.0); $p<0.001$ ). None of the participants refused blood draw and only three females did not provide a urine sample as required. All participants completed the questionnaire. Most questions on the questionnaire had a $99 \%$ response rate or higher, although some questions, particularly those relating to sexual behavior had a slightly higher proportion of missing data (e.g. response rate for questions relating to condom use was $98 \%$; 'ever been forced to have sex' had a response rate of $95 \%$ ).

\section{Orphanhood}

Overall 2375/6780 (35\%; 95\% confidence interval (CI): 33.9-36.2) of participants had lost one or both parents (1227 male; 1148 female); 11 students $(0.2 \%)$ did not report their parents' vital status. The majority of participants who had lost parent(s) were paternal orphans $(20 \% ; n=1352) ; 6 \%(n=378)$ were maternal, and $9 \%(n=645)$ double orphans.

Table 1 shows the demographic characteristics of orphans compared to non-orphans and also distribution by orphan type. The proportion of orphans was the same among both 
males and females and there was a similar proportion in each age group among orphans and non-orphans.

(Table 1)

Orphans were significantly $(p<0.001)$ more likely to live only with extended family $(30 \%$ vs. $2 \%$ of non-orphans) or with no family ( $8 \%$ vs. $0.5 \%$ non-orphans). Paternal orphans usually continued to live with their mothers (1226/1352; 91\%). By contrast, maternal orphans were more likely $(p<0.001)$ to be living with their extended family $(25 \%$; $93 / 378)$ or with no family $(4 \% ; 16 / 378)$. Over $20 \%(140 / 645)$ of double orphans did not live with a family member. Maternal and double orphans were more likely $(p<0.001)$ to reside in households with older household heads (most likely their grandparents) than paternal orphans; $50 \%$ of maternal and double orphans lived with a household head 50 years or older vs. 35\% paternal orphans; although 44\% (1153/2613) of non-orphans also resided in households with older household heads. The majority of orphans lived in female-headed households $(62 \%(1255 / 2375)$ of orphans vs. $26 \%(959 / 4405)$ of non-orphans; $p<0.001)$.

There was no evidence to suggest that orphans lived in poorer or richer households than non-orphans, based on answers to the socio-economic questions included on the questionnaire. They were not more or less likely to report being given pocket money or having done work to earn money than non-orphans; and there was no significant difference in physical household structure, or in the ownership of fixed and sellable assets reported by the two groups. (Fixed assets were determined by type of toilet and water source for bathing; sellable assets included ownership of livestock, bicycle, radio or tv).

\section{The relationship between orphanhood and knowledge, attitudes and behaviour}

Table 2 shows the association between orphanhood and knowledge, self-esteem, mattering, hopes, aspirations and thoughts for the future, and self-efficacy as well as selfreported behaviours (drinking alcohol, sexual experience, number of partners, forced sex 
and condom use) by gender. The odds ratios are adjusted for age and province. Figure 2 presents Kaplan-Meier survival estimates for age of sexual debut by orphan status.

(Table 2)

(Figure 2)

Among males there was evidence that orphans had less knowledge about HIV and prevention of HIV (adjusted odds ratio $(A O R)=0.88[95 \% \mathrm{Cl}: 0.77-1.00 ; p=0.046]$ for knowledge item 'know about HIV/AIDS' and AOR=0.85 [95\% Cl: 0.73-1.00; $p=0.045]$ for item 'know that condoms can prevent HIV'). Whilst male double orphans report perceiving that they matter less to those around them (AOR for item 'nobody cares enough to criticise me'=1.54; $95 \% \mathrm{Cl}: 1.16-2.04)$, there was no other evidence of association between male orphanhood and self-esteem or self-efficacy. Orphans more often reported drinking alcohol (AOR=1.28; 95\% $\mathrm{Cl}: 1.07-1.52)$; there was borderline significant evidence $(0.05<p$-value $<0.1)$ that male orphans were more likely to report not using a condom at first sex (AOR=1.30; 95\% Cl: 0.97-1.74), and to report earlier age of sexual debut (Hazard Ratio $(\mathrm{HR})=1.28 ; 95 \% \mathrm{Cl}$ : 0.98-1.67; see Figure 2). Double orphans in particular, reported heightened sexual risk; they were more likely to be sexually active ( $A O R=1.52$; 95\% Cl: 1.13-2.05); and to have experienced earlier sexual debut $(\mathrm{HR}=1.77 ; 95 \% \mathrm{Cl}$ : 1.22-2.56); and were more than three times as likely to report being forced at first sex (AOR=3.73; 95\% Cl: 1.37-10.18). Maternal male orphans also reported aspects of increased sexual risk (borderline evidence for early sexual debut $\mathrm{HR}=1.58$ [95\% $\mathrm{Cl}$ : 0.98 2.56]; AOR for no condom at first sex=2.00 [95\% Cl: 1.23-3.25]); the same associations were not seen amongst paternal male orphans (HR for early sexual debut $=0.95 ; 95 \% \mathrm{Cl}$ : 0.66-1.36). There was no evidence of association between orphanhood and either sexual refusal self-efficacy or condom self-efficacy amongst males. 
The right half of Table 2 presents data for female participants. There was no difference between orphans and non-orphans in terms of knowledge, self-esteem or self-efficacy. However, it does not appear that female orphans felt they mattered less than non-orphans (AOR for 'nobody cares enough to criticise me'=0.75 [95\% Cl: 0.60-0.93]; AOR for 'I am not somebody people turn to'=0.86 [95\% Cl: $0.74-1.00 ; p=0.049])$. There was though, evidence that female orphans had lower hopes for their future education reporting that they thought it was unlikely they would be able to attend college or university by the time they were $18(\mathrm{AOR}=0.84 ; 95 \% \mathrm{Cl}: 0.74-0.96)$. Only 94 females reported being sexually active ( $3 \%$ vs. $12 \%(410)$ males; $p<0.001)$; there was no significant association between orphanhood and reporting ever having had sex. However, female orphans were significantly more likely to report earlier sexual debut (see Figure $2 ; \mathrm{HR}=1.81 ; 95 \% \mathrm{Cl}$ : 1.03-3.17), being forced at first sex (AOR=1.97; 95\% Cl: 1.02-3.78) and not using condoms during their sexual encounters (AOR=2.02; 95\% Cl: 1.09-3.75), than nonorphans. Double orphans were at the highest risk being more than three times as likely to report forced first sex $(\mathrm{AOR}=3.33 ; 95 \% \mathrm{Cl}: 1.45-7.64)$ and 3.4 times as likely to report not ever using condoms (95\% Cl: 1.60-7.20); there was also borderline evidence of reported earlier sexual debut ( $\mathrm{HR}=2.09 ; 95 \% \mathrm{Cl}$ : 0.94-4.68). There was though, no evidence of the same increased sexual risk amongst maternal and paternal female orphans (HR for early sexual debut=1.78 (95\% Cl: 0.61-5.15) and 1.67 (95\% Cl: 0.85-3.29) respectively).

\section{Prevalence of HIV infection and risk factors for HIV}

All 6791 participants had a blood sample tested for HIV-1; 51 participants were HIV positive (0.75\%; 95\% Cl: 0.56-0.99). HIV-1 prevalence among girls was $0.95 \%(95 \% \mathrm{Cl}$ : $0.62-1.28 ; n=31)$ and among boys $0.57 \%(95 \% \mathrm{Cl}: 0.32-0.82 ; n=20)$.

Orphans were significantly more likely to be HIV-1 infected than non-orphans (age-sex adjusted OR=3.41; 95\% Cl: 1.76-6.60; AOR for males=2.93 [95\% Cl: 1.24-6.93]; AOR for females=3.90 [95\% Cl: $1.46-10.40])$. Almost two thirds (33/51) of those identified with HIV 
infection were orphans, $18(55 \%)$ had lost their father, 7 (21\%) had lost their mother and 8 (24\%) both parents. The proportion of HIV infections attributable to orphaning was $45.5 \%$ (95\% Cl: 21.1-62.4; adjusted for age and sex); population attributable fractions by type of orphaning (age-sex adjusted) indicate that $10.7 \%$ of HIV infections (95\% Cl: $0.4-19.9)$ were attributable to loss of mother only; $24.3 \%(95 \% \mathrm{Cl}: 6.9-38.4)$ to loss of father only, and $10.5 \%(95 \% \mathrm{Cl}: 0.0-38.5)$ to loss of both parents.

Only 12 (0.2\%; 95\% Cl: 0.1-0.4) participants were HSV-2 positive (4 males; 8 females) with no significant difference in prevalence between orphans and non-orphans in either males $(p=0.092)$ or females $(p=0.105)$. None of the males that were HSV-2 positive were co-infected with HIV, but 2/8 HSV-2 positive females were also HIV positive.

Table 3 presents crude and adjusted odds ratios assessing which factors were associated with an increased risk of HIV infection amongst male and female participants. Among males, orphanhood was the only factor significantly associated with increased risk of HIV after adjustment $(\mathrm{AOR}=2.91 ; 95 \% \mathrm{Cl}: 1.25-6.75)$, although there was borderline evidence that believing that you will have got somebody pregnant by the time you are 18 was also independently associated with increased risk (AOR=2.16; 95\% Cl: 0.98-4.72; $\mathrm{p}=0.055)$.

Orphanhood, having worked for money, thinking you would be pregnant by 18 , sexualrefusal self-efficacy and HSV-2 infection were all independently associated $(p<0.05)$ with increased HIV risk among females. Female orphans were at more than four times greater risk of HIV than female non-orphans (AOR=4.17; 95\% Cl: 1.53-11.33). Those who had ever done any work to earn money were almost two times more likely to be HIV positive than females who had never earned any income (AOR=1.90; $95 \% \mathrm{Cl}: 1.05-3.43)$.

Believing that you would be pregnant by the time you were 18 was also positively associated with increased HIV risk ( $\mathrm{AOR}=2.76$; $95 \% \mathrm{Cl}$ : 1.30-5.88), as was a high level of sexual refusal self-efficacy (those females who believed they would be able to stop 
somebody pressuring them to have sex were two times as likely to be HIV positive; AOR=2.16 [95\% Cl: 1.12-4.17). The association of HIV with HSV-2 in females was highly significant $(A O R=33.43 ; 95 \% \mathrm{Cl} 8.77-127.51)$. One factor that appeared to be associated with decreased risk of HIV was living in a household with 5 or more under the age of 20 years old (AOR=0.18; 95\% Cl: 0.04-0.76).

(Table 3)

\section{Discussion}

This was a large study of a representative sample of secondary school-attending youth residing in rural Zimbabwe. School-attending youth are generally assumed to be less likely to be orphans than those who do not attend school. Despite this, the rates of orphaning in this population were high with over a third having lost one or both parents. Furthermore, even though the overall prevalence of HIV and sexually acquired biomarkers is relatively low $(<1 \%)$, these data show a strong association between orphanhood and increased risk of HIV infection, with male orphans at almost three times greater risk of being infected and female orphans at four times greater risk. The population attributable fraction further indicates that nearly half of all the HIV infections in this cohort might be attributable to orphanhood. Whilst cross-sectional data does not normally allow one to determine a causative effect, in this instance it does seem plausible as reverse causality (i.e. the HIV status of the child being the cause of orphaning) would be unlikely. There is also evidence of higher rates of sexual risk taking among orphans, particularly among female orphans, with orphans more likely to report an earlier sexual debut, being forced to have sex against their will at first sex, and not using condoms. These data concur with the results from other population-based studies conducted in Zimbabwe (Birdthistle et al., 2008; Gregson et al., 2005) and within the region (Bicego, Rutstein, \& Johnson, 2003; Hosegood et al., 2007; Thurman, Brown, Richter, Maharaj, \& Magnani, 2006). 
Whilst the possibility of long-term survival following mother-to-child transmission among some of the HIV positive orphans cannot be dismissed (Ferrand et al., 2007; Marston, Zaba, Salomon, Brahmbhatt, \& Bagenda, 2005), other research has shown that the proportion of vertically infected children who survive to adolescence in absence of treatment, is likely to be quite low even for those children who are slow progressors (Brahmbhatt et al., 2006; Crampin et al., 2003; Ferrand et al., 2007; Schim van der Loeff et al., 2003; Stover et al., 2008; Zaba et al., 2005). There are a number of factors that suggest that the higher risk of HIV amongst these orphans is more likely the result of sexual acquisition than vertical transmission. Firstly, more than half of those who were HIV positive orphans had only lost their fathers. If vertical transmission were the main mode of infection among orphans infected with HIV we would expect to see higher rates of maternal and double orphaning within this group (Andrews et al., 2006; Hosegood et al., 2007; Monasch \& Boerma, 2004). It is possible that maternal survival here could be result of mothers being infected later; however, they would have had to survive at least 15 years post-infection to be alive at the time of the survey which is unlikely in this context. Secondly, there was increased reporting of sexual risk taking by orphans, particularly among young women. There is also borderline significant evidence of a difference in HIV prevalence between males and females, which is suggestive of sexual acquisition (if vertical acquisition was the main mode of transmission we would expect prevalence of HIV in males and females to be the same) although given the low numbers infected with HIV in this population it is difficult to determine with any certainty whether this unequal sex ratio of HIV infection is real.

We found no evidence of an association between HIV infection and participants reporting that they had ever had sex. This is likely to be for two reasons; firstly the number of participants infected with HIV and reporting being sexually active were both very low; and secondly there is likely some mis-classification of sexual behaviour (Cowan et al., 2008). We have reported elsewhere that we found inconsistencies in our behavioural data, with a 
number of participants reporting being sexually active in some questions and not sexually active in others. In addition, none of the four girls found to be pregnant at the time of the survey reported having had sex on their questionnaire (Cowan et al., 2008). For schoolattending youth in Zimbabwe, the penalty for disclosing sexual activity is high and can include corporal punishment and expulsion from school (Mavhu, Langhaug, Manyonga, Power, \& Cowan, 2008). The issue of validity of sexual behaviour data has arisen in other studies conducted in Zimbabwe (Gregson et al., 2002; Ministry of Health and Child Welfare (Zimbabwe), Zimbabwe National Family Planning Council, National AIDS Council (Zimbabwe), \& US Centers for Disease Control and Prevention, 2004) and elsewhere in Africa, particularly among young people (Hayes et al., 2005; Hewett, Mensch, \& Erulkar, 2004; Mensch, Hewett, \& Erulkar, 2003; Plummer et al., 2004). We found no evidence that the validity of the sexual behaviour data was worse among orphans or those that were HIV positive; they were no more or less likely to report sexual behaviour data inconsistently than non-orphans or those not infected with HIV (data not shown).

Subsequent studies have been conducted in order to evaluate improved methods for measuring sexual behaviour; data from these later surveys making use of these methods will be reported elsewhere by the authors in due course.

There is no evidence to suggest that orphans were economically disadvantaged or had lower self-esteem than non-orphans. This differs from data from population-based studies conducted in Zimbabwe and within the region (Bicego et al., 2003; Central Statistical Office (CSO) [Zimbabwe] and Macro International Inc., 2007; Nyamukapa et al., 2008) although the socio-economic questions included in this survey were limited. Not surprisingly, the prevalence of HIV was also lower in this school-going population than in population-based surveys of young people (Central Statistical Office (CSO) [Zimbabwe] and Macro International Inc., 2007; Ministry of Health and Child Welfare (Zimbabwe) et al., 2004) or in studies of orphans per se (Birdthistle et al., 2008) conducted in Zimbabwe around the same period. This is likely due to the fact that our study population was 
younger (mean age 15) and only included young people who were attending secondary school. Being in school and higher educational attainment have both been shown to be protective against HIV and to be associated with a variety of other outcomes (including delayed sexual debut and lower sexual risk) (Glynn et al., 2004; Hargreaves et al., 2008).

Children who have lost their mother are particularly vulnerable, as mothers play the main caring role and provide emotional support for their children in many settings in Africa (Bicego et al., 2003; Birdthistle et al., 2008; Case \& Ardington, 2006; Gregson et al., 2005; Monasch \& Boerma, 2004). Surviving mothers tend to be more committed to securing their children's education than surviving fathers (Nyamukapa \& Gregson, 2005), and, as was also seen here, paternal orphans are more likely to remain with their surviving parent and within the extended family safety net than those children who have lost their mothers (Hosegood et al., 2007; Monasch \& Boerma, 2004). One limitation with these data is that we are not able to assess the impact of orphanhood, and particularly maternal orphaning, on educational attainment as all participants were in school (Andrews et al., 2006; Bicego et al., 2003; Case \& Ardington, 2006; Ferrand et al., 2007; Floyd et al., 2007; Foster \& Williamson, 2000; Gregson et al., 2005; Nyamukapa \& Gregson, 2005). Orphans attending school may be very different from orphans in the community, however by selecting school orphans and comparing them to school-attending children we have controlled for a number of other socio-demographic and economic factors.

\section{Conclusion}

In summary, even among this group of school-attending youth, the rates of orphaning were high and there was a strong association between orphanhood and increased risk of HIV, with the population attributable fraction indicating that nearly half of all the HIV infections in this cohort of young people might be attributable to orphanhood. There was also evidence of higher rates of sexual risk taking among orphans, and the pattern of infection among orphans indicates that the higher rates of HIV are more likely the result of sexual rather than vertical transmission. 
At this stage it appears that the extended family safety net has continued to absorb the increasing number of orphans within these communities (Foster \& Williamson, 2000; Monasch \& Boerma, 2004; Nyamukapa \& Gregson, 2005; Watts, Lopman, Nyamukapa, \& Gregson, 2005). However, as the number of orphans, particularly double orphans, within Zimbabwe and southern Africa continues to rise, it will become increasingly important to fully elucidate the mechanisms by which orphaned and vulnerable children are at increased risk. Interventions that aim to mitigate the excess risk due to orphanhood could have an important effect on the HIV epidemic in Zimbabwe. Not enough is known about preventing HIV in young people, including orphans (UNAIDS Interagency Task Team on Young People, 2006), and further research is needed in order for us to clearly identify those children at greatest risk and target HIV prevention interventions and support for these children accordingly. 
AIDS Care, Month, Year; Vol(Iss): pp-pp

\section{Acknowledgements:}

The study is funded through the National Institute of Mental Health

\section{Notes on contributors:}

Anonymised 


\section{References:}

Andrews, G., Skinner, D., \& Zuma, K. (2006). Epidemiology of health and vulnerability among children orphaned and made vulnerable by HIV/AIDS in sub-Saharan Africa. AIDS Care, 18(3), 269-276.

Bicego, G., Rutstein, S., \& Johnson, K. (2003). Dimensions of the emerging orphan crisis in sub-Saharan Africa. Social Science \& Medicine, 56(6), 1235-1247.

Birdthistle, I. J., Floyd, S., Machingura, A., Mudziwapasi, N., Gregson, S., \& Glynn, J. R. (2008). From affected to infected? Orphanhood and HIV risk among female adolescents in urban Zimbabwe. Aids, 22(6), 759-766.

Brahmbhatt, H., Kigozi, G., Wabwire-Mangen, F., Serwadda, D., Lutalo, T., Nalugoda, F., et al. (2006). Mortality in HIV-infected and uninfected children of HIV-infected and uninfected mothers in rural Uganda. Journal of Acquired Immune Deficiency Syndromes, 41(4), 504-508.

Case, A., \& Ardington, C. (2006). The impact of parental death on school outcomes: longitudinal evidence from South Africa. Demography, 43(3), 401-420.

Central Statistical Office (CSO) [Zimbabwe] and Macro International Inc. (2007). Zimbabwe Demographic and Health Survey 2005-06.

Cowan, F. M., Pascoe, S. J., Langhaug, L. F., Dirawo, J., Chidiya, S., Jaffar, S., et al. (2008). The Regai Dzive Shiri Project: a cluster randomised controlled trial to determine the effectiveness of a multi-component community-based HIV prevention intervention for rural youth in Zimbabwe--study design and baseline results. Tropical Medicine \& International Health, 13(10), 1235-1244.

Crampin, A. C., Floyd, S., Glynn, J. R., Madise, N., Nyondo, A., Khondowe, M. M., et al. (2003). The long-term impact of HIV and orphanhood on the mortality and physical well-being of children in rural Malawi. Aids, 17(3), 389-397.

Ferrand, R. A., Luethy, R., Bwakura, F., Mujuru, H., Miller, R. F., \& Corbett, E. L. (2007). HIV infection presenting in older children and adolescents: a case series from Harare, Zimbabwe. Clinical Infectious Diseases, 44(6), 874-878. 
Floyd, S., Crampin, A. C., Glynn, J. R., Madise, N., Mwenebabu, M., Mnkhondia, S., et al. (2007). The social and economic impact of parental HIV on children in northern Malawi: retrospective population-based cohort study. AIDS Care, 19(6), 781-790.

Foster, G., \& Williamson, J. (2000). A review of current literature on the impact of HIV/AIDS on children in sub-Saharan Africa. Aids, 14 (Suppl 3), 275-284.

Glynn, J. R., Carael, M., Buve, A., Anagonou, S., Zekeng, L., Kahindo, M., et al. (2004). Does increased general schooling protect against HIV infection? A study in four African cities. Tropical Medicine \& International Health, 9(1), 4-14.

Gregson, S., Nyamukapa, C. A., Garnett, G. P., Mason, P. R., Zhuwau, T., Carael, M., et al. (2002). Sexual mixing patterns and sex-differentials in teenage exposure to HIV infection in rural Zimbabwe. Lancet, 359(9321), 1896-1903.

Gregson, S., Nyamukapa, C. A., Garnett, G. P., Wambe, M., Lewis, J. J., Mason, P. R., et al. (2005). HIV infection and reproductive health in teenage women orphaned and made vulnerable by AIDS in Zimbabwe. AIDS Care, 17(7), 785-794.

Hargreaves, J. R., Bonell, C. P., Boler, T., Boccia, D., Birdthistle, I., Fletcher, A., et al. (2008). Systematic review exploring time trends in the association between educational attainment and risk of HIV infection in sub-Saharan Africa. Aids, 22(3), 403-414.

Hayes, R. J., Changalucha, J., Ross, D. A., Gavyole, A., Todd, J., Obasi, A. I., et al. (2005). The MEMA kwa Vijana project: design of a community randomised trial of an innovative adolescent sexual health intervention in rural Tanzania. Contemporary Clinical Trials, 26(4), 430-442.

Hewett, P. C., Mensch, B. S., \& Erulkar, A. S. (2004). Consistency in the reporting of sexual behaviour by adolescent girls in Kenya: a comparison of interviewing methods. Sexually Transmitted Infections, 80 (Suppl 2), 43-48.

Hosegood, V., Floyd, S., Marston, M., Hill, C., McGrath, N., Isingo, R., et al. (2007). The effects of high HIV prevalence on orphanhood and living arrangements of 
children in Malawi, Tanzania, and South Africa. Population Studies (Cambridge), 61(3), 327-336.

Marston, M., Zaba, B., Salomon, J. A., Brahmbhatt, H., \& Bagenda, D. (2005). Estimating the net effect of HIV on child mortality in African populations affected by generalized HIV epidemics. Journal of Acquired Immune Deficiency Syndromes, 38(2), 219-227.

Mavhu, W., Langhaug, L., Manyonga, B., Power, R., \& Cowan, F. (2008). What is 'sex' exactly? Using cognitive interviewing to improve the validity of sexual behaviour reporting among young people in rural Zimbabwe. Culture Health \& Sexuality, 10(6), 563-572.

Mensch, B. S., Hewett, P. C., \& Erulkar, A. S. (2003). The reporting of sensitive behavior by adolescents: a methodological experiment in Kenya. Demography, 40(2), 247-268.

Ministry of Health and Child Welfare (Zimbabwe), Zimbabwe National Family Planning Council, National AIDS Council (Zimbabwe), \& US Centers for Disease Control and Prevention. (2004). The Zimbabwe Young Adult Survey (YAS) 2001-2002 Final Report. Retrieved. from.

Monasch, R., \& Boerma, J. T. (2004). Orphanhood and childcare patterns in subSaharan Africa: an analysis of national surveys from 40 countries. Aids, 18 (Suppl 2), 55-65.

Nyamukapa, C. A., \& Gregson, S. (2005). Extended family's and women's roles in safeguarding orphans' education in AIDS-afflicted rural Zimbabwe. Social Science \& Medicine, 60(10), 2155-2167.

Nyamukapa, C. A., Gregson, S., Lopman, B., Saito, S., Watts, H. J., Monasch, R., et al. (2008). HIV-associated orphanhood and children's psychosocial distress: theoretical framework tested with data from Zimbabwe. American Journal of Public Health, 98(1), 133-141. 
Parikh, A., Desilva, M. B., Cakwe, M., Quinlan, T., Simon, J. L., Skalicky, A., et al. (2007). Exploring the Cinderella myth: intrahousehold differences in child wellbeing between orphans and non-orphans in Amajuba District, South Africa. Aids, 21 (Suppl 7), 95-103.

Plummer, M. L., Ross, D. A., Wight, D., Changalucha, J., Mshana, G., Wamoyi, J., et al. (2004). "A bit more truthful": the validity of adolescent sexual behaviour data collected in rural northern Tanzania using five methods. Sexually Transmitted Infections, 80 (Suppl 2), 49-56.

Schim van der Loeff, M. F., Hansmann, A., Awasana, A. A., Ota, M. O., O'Donovan, D., Sarge-Njie, R., et al. (2003). Survival of HIV-1 and HIV-2 perinatally infected children in The Gambia. Aids, 17(16), 2389-2394.

Stover, J., Johnson, P., Zaba, B., Zwahlen, M., Dabis, F., \& Ekpini, R. E. (2008). The Spectrum projection package: improvements in estimating mortality, ART needs, PMTCT impact and uncertainty bounds. Sexually Transmitted Infections, 84 Suppl 1, i24-i30.

Thurman, T. R., Brown, L., Richter, L., Maharaj, P., \& Magnani, R. (2006). Sexual risk behavior among South African adolescents: is orphan status a factor? AIDS and Behaviour, 10(6), 627-635.

UNAIDS Interagency Task Team on Young People. (2006). Preventing HIV/AIDS in Young People: Systematic Reviews of the Evidence from Developing Countries, Technical Report Series 938: WHO, Geneva.

UNAIDS/WHO. (2008). Epidemiological Fact Sheet on HIV and AIDS. 2008 Update Zimbabwe.

UNICEF. (2006). Africa's Orphaned and Vulnerable Generations: Children affected by AIDS: UNICEF.

US Department of Health and Human Services. (2000). Serologic assays for human immunodeficiency virus antibody in dried blood specimens collected on filter paper. Retrieved. from. 
US National Committee for Clinical Laboratory Standards. (1997). Blood Collection on Filter Paper for Neonatal Screening Programs (LA4A). Retrieved 25 February 2008, from www.csli.org

Watts, H., Lopman, B., Nyamukapa, C., \& Gregson, S. (2005). Rising incidence and prevalence of orphanhood in Manicaland, Zimbabwe, 1998 to 2003. Aids, 19(7), 717-725.

Zaba, B., Whitworth, J., Marston, M., Nakiyingi, J., Ruberantwari, A., Urassa, M., et al. (2005). HIV and mortality of mothers and children: evidence from cohort studies in Uganda, Tanzania, and Malawi. Epidemiology, 16(3), 275-280. 
Figure 1: Location of three study provinces within Zimbabwe

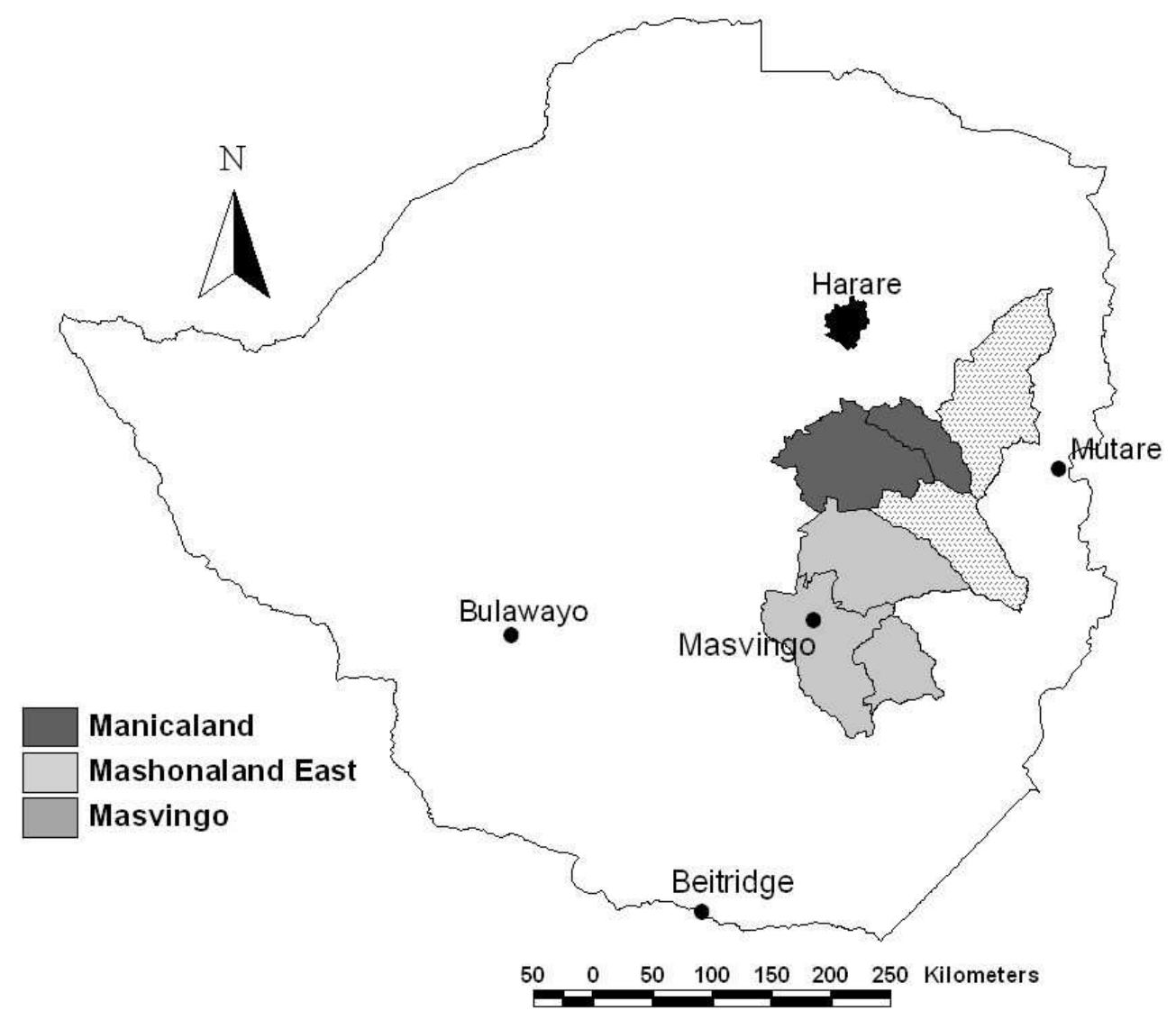


Figure 2: Survival time to age of sexual debut by orphan status
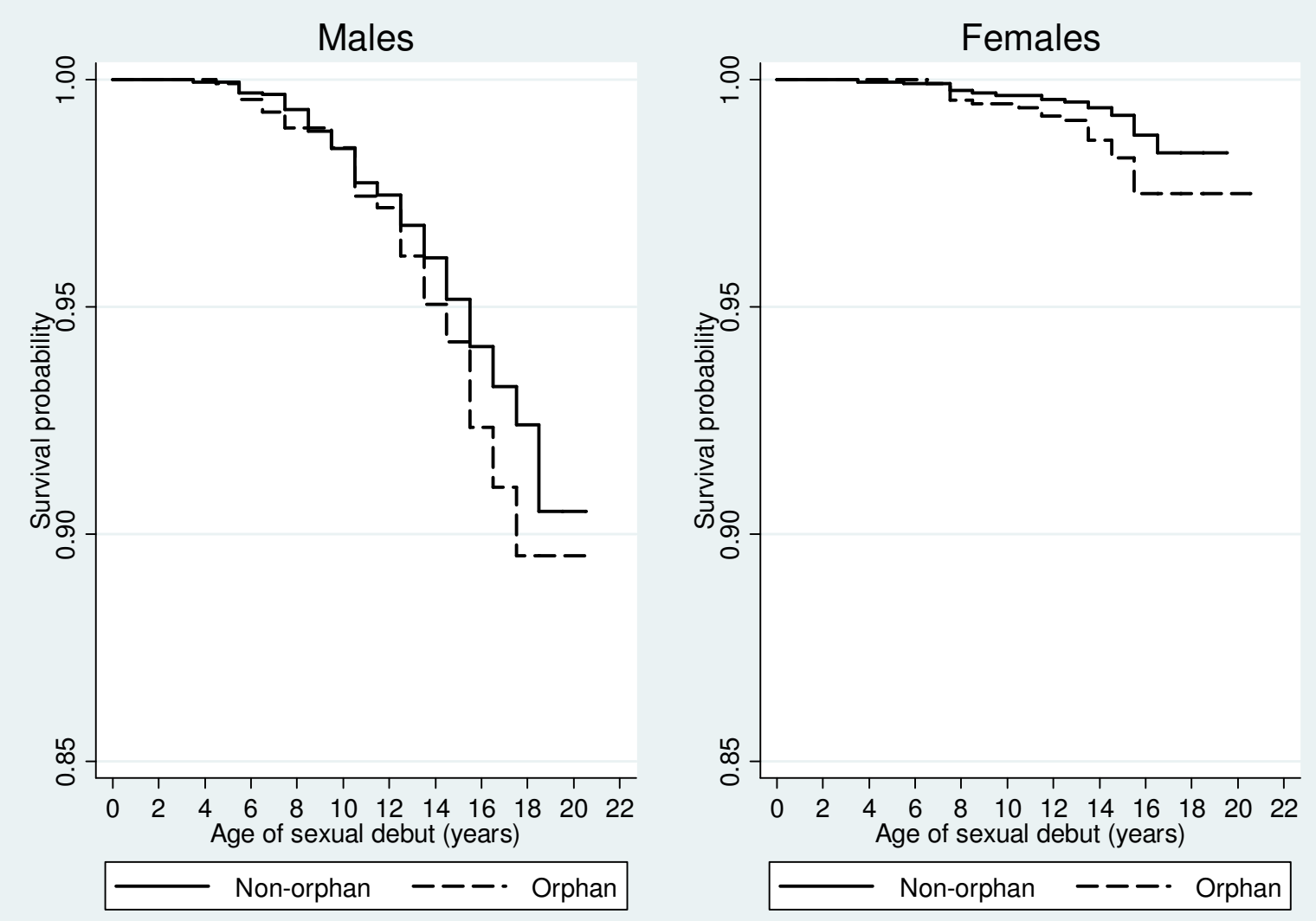
Table 1: Demographic characteristics by orphanhood status

\begin{tabular}{|c|c|c|c|c|c|c|c|c|c|c|}
\hline \multirow[t]{2}{*}{ Characteristic } & \multicolumn{2}{|c|}{$\begin{array}{c}\text { Non-orphans } \\
(n=4405)\end{array}$} & \multicolumn{2}{|c|}{$\begin{array}{l}\text { Orphans } \\
(n=2375)\end{array}$} & \multicolumn{2}{|c|}{$\begin{array}{c}\text { Maternal } \\
\text { orphans }(n=378)\end{array}$} & \multicolumn{2}{|c|}{$\begin{array}{c}\text { Paternal orphans } \\
\quad(n=1352)\end{array}$} & \multicolumn{2}{|c|}{$\begin{array}{l}\text { Dual orphans } \\
\quad(n=645)\end{array}$} \\
\hline & $\mathbf{n}$ & (\%) & $n$ & (\%) & $\mathbf{n}$ & (\%) & $\mathbf{n}$ & (\%) & $\mathbf{n}$ & (\%) \\
\hline \multicolumn{11}{|l|}{ Demographic: } \\
\hline \multicolumn{11}{|l|}{ Province: } \\
\hline Manicaland & 1482 & 33.6 & 825 & 34.7 & 123 & 32.5 & 478 & 35.4 & 224 & 34.7 \\
\hline Mashonaland East & 1042 & 23.7 & 624 & 26.3 & 110 & 29.1 & 341 & 25.2 & 173 & 26.8 \\
\hline Masvingo & 1881 & 42.7 & 926 & 39.0 & 145 & 38.4 & 533 & 39.4 & 248 & 38.4 \\
\hline \multicolumn{11}{|l|}{ Gender: } \\
\hline Male & 2288 & 51.9 & 2117 & 51.7 & 198 & 52.4 & 689 & 51.0 & 340 & 52.7 \\
\hline Female & 1227 & 48.1 & 1148 & 48.3 & 180 & 47.6 & 663 & 49.0 & 305 & 47.3 \\
\hline \multicolumn{11}{|l|}{ Age: } \\
\hline Mean (years) & & 15.2 & & 15.2 & & 15.2 & & 15.2 & & 15.2 \\
\hline Under 15yrs & 1162 & 26.4 & 620 & 26.1 & 89 & 23.5 & 357 & 26.4 & 174 & 27.0 \\
\hline $15-16$ yrs & 2728 & 61.9 & 1497 & 63.0 & 244 & 64.6 & 858 & 63.5 & 395 & 61.2 \\
\hline $17-18 y r s$ & 480 & 10.9 & 237 & 10.0 & 41 & 10.8 & 126 & 9.3 & 70 & 10.8 \\
\hline 19yrs or older & 35 & 0.8 & 21 & 0.9 & 4 & 1.1 & 11 & 0.8 & 6 & 0.9 \\
\hline \multicolumn{11}{|l|}{ Household structure } \\
\hline \multicolumn{11}{|l|}{ Live with: } \\
\hline Both parents $+/-$ extended family & 1813 & 41.2 & & & & & & & & \\
\hline Parent+/- extended family & 2487 & 56.5 & 1495 & 62.9 & 269 & 71.2 & 1226 & 90.7 & & \\
\hline Extended family only & 81 & 1.8 & 703 & 29.6 & 93 & 24.6 & 105 & 7.8 & 505 & 78.3 \\
\hline Do not live with any family & 24 & 0.5 & 177 & 7.5 & 16 & 4.2 & 21 & 1.6 & 140 & 21.7 \\
\hline \multicolumn{11}{|l|}{ Head of household: } \\
\hline Male & 2682 & 73.7 & 753 & 37.5 & 217 & 68.9 & 259 & 22.5 & 277 & 51.1 \\
\hline Female & 959 & 26.3 & 1255 & 62.5 & 98 & 31.1 & 892 & 77.5 & 265 & 48.9 \\
\hline \multicolumn{11}{|l|}{ Age of household head (years) ${ }^{a}$ : } \\
\hline 20 or younger & 211 & 8.1 & 143 & 9.6 & 23 & 10.2 & 63 & 7.3 & 57 & 14.2 \\
\hline $21-50$ years & 1249 & 47.8 & 732 & 49.3 & 90 & 39.8 & 500 & 58.2 & 142 & 35.5 \\
\hline$>50$ years & 1153 & 44.1 & 610 & 41.1 & 113 & 50.0 & 296 & 34.5 & 201 & 50.3 \\
\hline \multicolumn{11}{|l|}{ Number in household: } \\
\hline Mean (no. of people) [95\% Cl] & \multicolumn{2}{|c|}{$1.95[1.92-1.97]$} & \multicolumn{2}{|c|}{$1.70[1.67-1.74]$} & \multicolumn{2}{|c|}{$1.81[1.72-1.91]$} & \multicolumn{2}{|c|}{$1.70[1.65-1.74]$} & \multicolumn{2}{|c|}{$1.65[1.58-1.72]$} \\
\hline 3 or more people & 4249 & 96.6 & 2195 & 92.6 & 352 & 93.4 & 1259 & 93.3 & 584 & 90.8 \\
\hline 5 or more under 20 years old & 1201 & 27.3 & 527 & 22.2 & 91 & 24.1 & 299 & 22.2 & 137 & 21.3 \\
\hline \multicolumn{11}{|l|}{ SES: } \\
\hline Ever had pocket money & 3438 & 78.5 & 1782 & 75.6 & 299 & 79.7 & 1039 & 77.5 & 444 & 69.3 \\
\hline Ever done work to earn money & 1593 & 36.5 & 846 & 35.9 & 150 & 40.4 & 472 & 35.1 & 224 & 35.0 \\
\hline Traditional dwelling (e.g. mud) & 1155 & 26.3 & 639 & 27.0 & 98 & 26.0 & 382 & 28.3 & 159 & 24.8 \\
\hline Pit latrine or bush toilet & 1651 & 37.7 & 867 & 36.7 & 142 & 37.7 & 490 & 36.5 & 235 & 36.8 \\
\hline River or stream for bathing & 891 & 20.7 & 414 & 17.9 & 70 & 18.9 & 246 & 18.6 & 98 & 15.8 \\
\hline Own livestock & 4263 & 96.8 & 2296 & 96.7 & 368 & 97.4 & 1305 & 96.5 & 623 & 96.6 \\
\hline Own scotchcart or bicycle & 2472 & 56.1 & 1341 & 56.5 & 211 & 55.8 & 762 & 56.4 & 368 & 57.0 \\
\hline Own radio or TV & 2576 & 58.5 & 1392 & 58.6 & 243 & 64.3 & 776 & 57.4 & 373 & 57.8 \\
\hline
\end{tabular}

${ }^{a}$ Data only available for 4104 participants 
Table 2: Association between orphanhood and knowledge, self-esteem, mattering, hopes \& aspirations, self-efficacy and behaviour, stratified by gender.

\begin{tabular}{|c|c|c|c|c|c|c|c|c|c|c|}
\hline \multirow[b]{3}{*}{ Characteristic/outcome } & \multicolumn{5}{|c|}{ Male } & \multicolumn{5}{|c|}{ Female } \\
\hline & \multicolumn{2}{|c|}{$\begin{array}{c}\text { Non-orphan } \\
(n=2288)\end{array}$} & \multicolumn{3}{|c|}{ Orphan $(n=1227)$} & \multicolumn{2}{|c|}{$\begin{array}{c}\text { Non-orphan } \\
(\mathrm{n}=2117)\end{array}$} & \multicolumn{3}{|c|}{ Orphan $(n=1148)$} \\
\hline & $n$ & $(\%)$ & $n$ & $(\%)$ & $\mathrm{AOR}^{+} \quad[95 \% \mathrm{Cl}]$ & $n$ & (\%) & $n$ & (\%) & $\mathrm{AOR}^{+} \quad[95 \% \mathrm{Cl}]$ \\
\hline \multicolumn{11}{|l|}{ Knowledge: } \\
\hline Know about HIV/AIDS & 895 & $(39.3)$ & 448 & $(36.7)$ & $0.88[0.77-1.00]$ & 619 & $(29.3)$ & 349 & $(30.6)$ & $1.06[0.88-1.28]$ \\
\hline Know that condoms can prevent HIV & 1009 & $(44.3)$ & 499 & $(40.8)$ & $0.85[0.73-1.00]$ & 514 & $(24.4)$ & 276 & $(24.1)$ & $0.98[0.82-1.17]$ \\
\hline \multicolumn{11}{|l|}{ Attitudes: } \\
\hline \multicolumn{11}{|l|}{ Self-esteem: } \\
\hline I am a failure & 804 & $(35.1)$ & 460 & $(37.5)$ & $1.10[0.98-1.24]$ & 752 & $(35.5)$ & 413 & $(36.0)$ & $1.02[0.89-1.17]$ \\
\hline \multicolumn{11}{|l|}{ Mattering: } \\
\hline People do not notice me & 843 & $(36.8)$ & 456 & $(37.2)$ & $1.02[0.89-1.17]$ & 719 & $(34.0)$ & 355 & $(30.9)$ & $0.88[0.71-1.08]$ \\
\hline Nobody cares enough to criticize me & 320 & $(14.0)$ & 189 & $(15.4)$ & $1.09[0.87-1.38]$ & 349 & $(16.5)$ & 151 & $(13.2)$ & $0.75[0.60-0.93]$ \\
\hline Am not someone people turn to & 807 & $(35.3)$ & 414 & $(33.7)$ & $0.94[0.79-1.13]$ & 700 & $(33.1)$ & 342 & $(29.8)$ & $0.86[0.74-1.00]$ \\
\hline \multicolumn{11}{|l|}{ Hopes and aspirations: When I am 18 I will.... } \\
\hline Maybe got someone pregnant $\left(\delta^{\Uparrow}\right) /$ be pregnant $(+$ ) & 450 & $(19.8)$ & 199 & $(16.3)$ & $0.80[0.65-0.98]$ & 352 & $(16.7)$ & 177 & $(15.5)$ & $0.92[0.79-1.08]$ \\
\hline Be at college or university & 1020 & $(46.6)$ & 527 & $(44.5)$ & $0.92[0.80-1.05]$ & 1070 & $(51.7)$ & 530 & $(47.8)$ & $0.84[0.74-0.96]$ \\
\hline \multicolumn{11}{|l|}{ Sexual-refusal self-efficacy: } \\
\hline Will stop somebody pressuring me to have sex & 1173 & $(51.5)$ & 623 & $(50.9)$ & $0.96[0.84-1.10]$ & 1046 & $(49.5)$ & 566 & $(49.5)$ & $1.00[0.87-1.15]$ \\
\hline Will refuse to have sex if don't want to & 1138 & $(49.9)$ & 649 & $(53.1)$ & $1.12[0.96-1.30]$ & 1027 & $(48.8)$ & 552 & $(48.3)$ & $0.98[0.83-1.17]$ \\
\hline It is not OK to force someone to have sex & 1976 & $(86.7)$ & 1055 & $(86.1)$ & $0.95[0.78-1.16]$ & 1830 & $(86.7)$ & 1010 & $(88.4)$ & $1.15[0.96-1.37]$ \\
\hline \multicolumn{11}{|l|}{ Condom self-efficacy: } \\
\hline Will use condoms in the future & 1032 & $(45.3)$ & 568 & $(46.4)$ & $1.03[0.87-1.21]$ & 362 & $(17.2)$ & 184 & $(16.1)$ & $0.93[0.75-1.15]$ \\
\hline Will tell my partner we must use condoms & 1096 & $(48.0)$ & 615 & $(50.2)$ & 1.07 [0.94-1.22] & 530 & $(25.1)$ & 249 & $(21.8)$ & $0.83[0.68-1.02]$ \\
\hline \multicolumn{11}{|l|}{ Behaviour: } \\
\hline \multicolumn{11}{|l|}{ Risky behaviours: } \\
\hline Have tried alcohol & 599 & $(26.3)$ & 377 & $(30.8)$ & $1.28[1.07-1.52]$ & 239 & $(11.3)$ & 136 & $(12.0)$ & $1.08[0.87-1.33]$ \\
\hline \multicolumn{11}{|l|}{ Sexual behaviour ${ }^{1}$ : } \\
\hline Ever had sex & 252 & $(11.2)$ & 158 & $(13.2)$ & 1.19 [0.94-1.50] & 53 & $(2.5)$ & 41 & (3.6) & $1.41[0.93-2.14]$ \\
\hline Sexual debut before $17^{2}$ & 120 & $(5.6)$ & 85 & (7.4) & $1.30[1.01-1.67]$ & 23 & (1.1) & 24 & (2.2) & $1.80[1.07-3.03]$ \\
\hline No. of partners - 2 or more ${ }^{3}$ & 49 & (2.2) & 33 & (2.8) & $1.24[0.83-1.86]$ & 6 & $(0.3)$ & 5 & $(0.4)$ & $1.40[0.64-3.08]$ \\
\hline Forced the first time had sex & 11 & $(0.5)$ & 11 & $(1.0)$ & $1.86[0.78-4.43]$ & 16 & $(0.8)$ & 18 & $(1.6)$ & $1.97[1.02-3.78]$ \\
\hline Ever been forced & 52 & (2.5) & 22 & $(2.0)$ & 0.79 [0.46-1.35] & 31 & $(1.5)$ & 25 & (2.2) & $1.44[0.83-2.51]$ \\
\hline Did not use condom at first sex & 96 & (4.3) & 67 & $(5.6)$ & $1.30[0.97-1.74]$ & 16 & $(0.8)$ & 18 & $(1.6)$ & $1.97[1.13-3.45]$ \\
\hline Did not use condom at last sex & 78 & (3.5) & 49 & $(4.1)$ & 1.16 [0.84-1.62] & 14 & $(0.7)$ & 16 & $(1.4)$ & $2.05[1.10-3.80]$ \\
\hline Never used a condom & 75 & (3.4) & 47 & (3.9) & 1.17 [0.83-1.65] & 14 & $(0.7)$ & 16 & $(1.4)$ & $2.02[1.09-3.75]$ \\
\hline
\end{tabular}

${ }^{\dagger}$ Adjusted for age and province

${ }^{1}$ Reference category in each case includes those who report they never had sex

${ }^{2}$ Reference category includes: $<17$ yrs and never had sex; $\geq 17 y$ rs and never had sex; $\geq 17 \mathrm{yrs}$ and sexual debut at $17 \mathrm{yrs}$ or older

${ }^{3}$ Adjusted OR for females obtained using logistic regression with robust standard errors to allow for clustering 
Table 3: Risk factors for HIV infection stratified by gender

\begin{tabular}{|c|c|c|c|c|c|c|c|c|}
\hline \multirow[b]{3}{*}{ Characteristic } & \multicolumn{4}{|c|}{ Male $(n=3521)$} & \multicolumn{4}{|c|}{ Female $(n=3270)$} \\
\hline & \multirow[b]{2}{*}{$\mathbf{n}$} & \multirow[b]{2}{*}{$\begin{array}{c}\% \text { HIV } \\
\text { +ve }\end{array}$} & Crude & Adjusted $^{1}$ & \multirow[b]{2}{*}{$\mathbf{n}$} & \multirow[b]{2}{*}{$\begin{array}{c}\% \text { HIV } \\
\text { +ve }\end{array}$} & Crude & Adjusted $^{1}$ \\
\hline & & & $\begin{array}{cc} & \text { Chi-square } \\
\text { OR } & \text { p-value } \\
& {[95 \% \mathrm{Cl}]} \\
\end{array}$ & $\begin{array}{cc} & \text { Chi-square } \\
\text { OR } & \text { p-value } \\
& {[95 \% \mathrm{Cl}]}\end{array}$ & & & $\begin{array}{cc} & \text { Chi-square p. } \\
\text { OR } & \text { value [95\% } \\
& \text { Cl] }\end{array}$ & $\begin{array}{c}\text { Chi-square } \\
\text { p-value } \\
{[95 \% \mathrm{Cl}]}\end{array}$ \\
\hline \multicolumn{9}{|l|}{ Demographic: } \\
\hline Province: & & & $p=0.301$ & $p=0.435$ & & & $p=0.059$ & $p=0.003$ \\
\hline Manicaland & 1181 & 0.8 & 1.00 & & 1129 & 0.3 & 1.00 & \\
\hline Mashonaland East & 863 & 0.7 & $0.92[0.42-2.06]$ & $0.86[0.41-1.83]$ & 804 & 1.2 & $4.61[1.12-19.06]$ & $6.04[1.53-23.78]$ \\
\hline Masvingo & 1477 & 0.3 & $0.53[0.21-1.33]$ & $0.61[0.27-1.36]$ & 1337 & 1.4 & $4.99[1.33-18.75]$ & $8.11[2.36-27.85]$ \\
\hline Age: & & & $p=0.423$ & $p=0.344$ & & & $p=0.886$ & $p=0.835$ \\
\hline Under 15yrs & 680 & 0.6 & 1.00 & & 1104 & 0.9 & 1.00 & \\
\hline $15-16$ yrs & 2229 & 0.7 & $1.10[0.41-2.96]$ & $1.13[0.45-2.84]$ & 2001 & 1.0 & $1.10[0.51-2.37]$ & $0.93[0.41-2.08]$ \\
\hline 17 years or older & 612 & 0.2 & $0.21[0.02-2.69]$ & $0.23[0.03-2.05]$ & 165 & 0.6 & $0.66[0.10-4.27]$ & $0.58[0.10-3.74]$ \\
\hline Orphan status: & & & $p=0.015^{2}$ & $p=0.013^{2}$ & & & $p=0.007^{2}$ & $p=0.005^{2}$ \\
\hline Non-orphan & 2288 & 0.4 & 1.00 & & 2117 & 0.5 & 1.00 & \\
\hline Maternal orphan & 198 & 0.5 & $1.58[0.29-8.59]$ & $1.51[0.25-9.18]$ & 180 & 3.3 & 7.27 [2.04-25.91] & 7.18 [2.08-24.73] \\
\hline Paternal orphan & 689 & 1.2 & $3.36[1.18-9.54]$ & $3.32[1.20-9.22]$ & 663 & 1.5 & $3.23[1.15-9.07]$ & $3.44[1.26-9.38]$ \\
\hline Dual orphan & 340 & 0.9 & $2.67[0.82-8.74]$ & $2.81[0.90-8.74]$ & 305 & 1.6 & $3.51[1.15-10.72]$ & $3.76[1.04-13.57]$ \\
\hline Orphan (lost one or both parents) & 1227 & 1.0 & $2.91[1.23-6.89]$ & $2.91[1.25-6.75]$ & 1148 & 1.8 & $3.93[1.46-10.58]$ & $4.17[1.53-11.33]$ \\
\hline \multicolumn{9}{|l|}{ Household structure: } \\
\hline Live with: & & & $p=0.003$ & $p=0.238$ & & & $p=0.048$ & $p=0.839$ \\
\hline Parent+/- extended family & 2997 & 0.4 & 1.00 & & 2798 & 0.8 & 1.00 & \\
\hline Extended family only or no family & 522 & 1.3 & $3.24[1.48-7.10]$ & $2.15[0.60-7.65]$ & 470 & 1.7 & $2.09[1.01-4.34]$ & $1.09[0.49-2.42]$ \\
\hline Head of household: & & & $p=0.056$ & $p=0.214$ & & & $p=0.015$ & $p=0.304$ \\
\hline Male & 1856 & 0.3 & 1.00 & & 1585 & 0.6 & 1.00 & \\
\hline Female & 1064 & 0.9 & $2.93[0.97-8.83]$ & $2.33[0.61-8.85]$ & 1154 & 1.5 & $2.58[1.20-5.51]$ & $1.57[0.66-3.71]$ \\
\hline Age of household head ${ }^{3}$ : & & & $p=0.707$ & $p=0.936$ & & & $p=0.943$ & $p=0.870$ \\
\hline 20 years or younger & 174 & 0.6 & 1.00 & & 180 & 1.1 & 1.00 & \\
\hline $21-50$ years & 989 & 0.3 & $0.48[0.07-3.20]$ & $0.71[0.09-5.31]$ & 996 & 1.0 & $0.90[0.22-3.69]$ & $0.66[0.14-3.12]$ \\
\hline 50 years or older & 958 & 0.3 & $0.48[0.07-3.20]$ & $0.69[0.08-6.13]$ & 807 & 0.9 & $0.80[0.19-3.27]$ & $0.75[0.20-2.78]$ \\
\hline Number of under $20 y r s$ in household: & & & $p=0.967$ & $p=0.828$ & & & $p=0.013$ & $p=0.020$ \\
\hline $1-4$ under 20 years old & 2665 & 0.6 & 1.00 & & 2382 & 1.2 & 1.00 & \\
\hline 5 or more under 20 years old & 848 & 0.6 & $1.02[0.31-3.36]$ & $1.13[0.37-3.45]$ & 883 & 0.2 & $0.18[0.05-0.70]$ & $0.18[0.04-0.76]$ \\
\hline \multicolumn{9}{|l|}{ SES: } \\
\hline Ever had pocket money: & & & $p=0.805$ & $p=0.723$ & & & $p=0.960$ & $p=0.948$ \\
\hline No & 797 & 0.6 & 1.00 & & 720 & 1.0 & 1.00 & \\
\hline Yes & 2698 & 0.6 & $0.89[0.35-2.26]$ & $0.85[0.35-2.07]$ & 2525 & 1.0 & $0.98[0.41-2.30]$ & $0.97[0.40-2.33]$ \\
\hline Ever done any work to earn money: & & & $p=0.279$ & $p=0.256$ & & & $p=0.054$ & $p=0.033$ \\
\hline No & 1813 & 0.7 & 1.00 & & 2473 & 0.8 & 1.00 & \\
\hline Yes & 1681 & 0.4 & $0.61[0.25-1.48]$ & $0.60[0.24-1.45]$ & 760 & 1.5 & $1.81[0.99-3.31]$ & $1.90[1.05-3.43]$ \\
\hline Dwelling: & & & $p=0.789$ & $p=0.959$ & & & $p=0.424$ & $p=0.559$ \\
\hline Traditional/Backyard structure & 930 & 0.5 & 1.00 & & 867 & 1.2 & 1.00 & \\
\hline Stones \& cement / modern structure & 2571 & 0.6 & $1.15[0.42-3.14]$ & $1.02[0.39-2.69]$ & 2397 & 0.9 & $0.76[0.38-1.49]$ & $0.81[0.40-1.64]$ \\
\hline Water for bathing: & & & $p=0.921$ & $p=0.0682$ & & & $p=0.140$ & $p=0.213$ \\
\hline Bath or bucket & 2737 & 0.6 & 1.00 & & 2583 & 0.8 & 1.00 & \\
\hline River or stream & 696 & 0.6 & $0.94[0.31-2.90]$ & $1.24[0.44-3.48]$ & 612 & 1.5 & $1.73[0.84-3.58]$ & $1.64[0.75-3.58]$ \\
\hline
\end{tabular}




\section{Table 3: Continued}

\begin{tabular}{|c|c|c|c|c|c|c|c|c|}
\hline \multirow[b]{3}{*}{ Characteristic } & \multirow[b]{3}{*}{$\mathbf{n}$} & \multirow[b]{3}{*}{$\begin{array}{l}\% \text { HIV } \\
+ \text { ve }\end{array}$} & \multicolumn{2}{|l|}{ Male $(n=3521)$} & \multirow[b]{3}{*}{$\mathbf{n}$} & \multirow{2}{*}{\multicolumn{2}{|c|}{$\begin{array}{l}\text { Female }(n=3270) \\
\text { Crude }\end{array}$}} & \multirow[b]{2}{*}{ Adjusted $^{1}$} \\
\hline & & & Crude & & & & & \\
\hline & & & $\begin{array}{cc} & \text { Chi-square } \\
\text { OR } & p \text {-value } \\
& {[95 \% \mathrm{Cl}]} \\
\end{array}$ & OR $\begin{array}{c}\text { Chi-square } \\
\mathrm{p} \text {-value } \\
{[95 \% \mathrm{Cl}]}\end{array}$ & & $\begin{array}{c}\% \text { HIV } \\
+ \text { +ve }\end{array}$ & $\begin{array}{cc} & \text { Chi-square p. } \\
\text { OR } & \text { value [95\% } \\
& \mathrm{Cl}] \\
\end{array}$ & $\begin{array}{cc} & \text { Chi-square } \\
\text { OR } & p \text {-value } \\
& {[95 \% \mathrm{Cl}]} \\
\end{array}$ \\
\hline \multicolumn{9}{|l|}{ Knowledge: } \\
\hline Know about HIVIAIDS: & & & $p=0.500$ & $p=0.529$ & & & $p=0.148$ & $p=0.285$ \\
\hline Little or nothing & 2159 & 0.6 & 1.00 & & 2787 & 0.8 & 1.00 & \\
\hline Quite a lot or a lot & 1345 & 0.4 & $0.69[0.23-2.05]$ & $0.72[0.26-2.00]$ & 969 & 1.3 & $1.71[0.83-3.56]$ & $1.48[0.72-3.04]$ \\
\hline Know that condoms can prevent HIV: & & & $p=0.272$ & $p=0.283$ & & & $p=0.104$ & $p=0.143$ \\
\hline No or not sure & 1997 & 0.4 & 1.00 & & 2471 & 0.8 & 1.00 & \\
\hline Yes & 1510 & 0.7 & $1.66[0.67-4.08]$ & $1.62[0.67-3.90]$ & 790 & 1.4 & $1.85[0.88-3.88]$ & $1.65[0.84-3.21]$ \\
\hline \multicolumn{9}{|l|}{ Attitudes: } \\
\hline \multicolumn{9}{|l|}{ Self-esteem: } \\
\hline I am a failure: & & & $p=0.410$ & $p=0.492$ & & & $p=0.335$ & $p=0.424$ \\
\hline No & 2255 & 0.5 & 1.00 & & 2104 & 1.1 & 1.00 & \\
\hline Yes & 1266 & 0.7 & $1.47[0.59-3.65]$ & $1.35[0.57-3.19]$ & 1166 & 0.7 & $0.62[0.24-1.62]$ & $0.66[0.24-1.81]$ \\
\hline \multicolumn{9}{|l|}{ Mattering: } \\
\hline People do not notice me: & & & $p=0.028$ & $p=0.211$ & & & $p=0.439$ & $p=0.523$ \\
\hline No - people do notice me & 2220 & 0.3 & 1.00 & & 2195 & 0.9 & 1.00 & \\
\hline Yes & 1301 & 1.0 & $3.20[1.13-9.06]$ & $0.60[0.27-1.33]$ & 1075 & 1.1 & $1.29[0.67-2.48]$ & $1.24[0.64-2.40]$ \\
\hline People who care enough to criticize me: & & & $p=0.887$ & $p=0.966$ & & & $p=0.746$ & $p=0.958$ \\
\hline Yes - there are people who care & 3010 & 0.6 & 1.00 & & 2769 & 1.0 & 1.00 & \\
\hline No - nobody cares & 511 & 0.6 & $1.12[0.25-5.01]$ & $1.03[0.25-4.19]$ & 501 & 0.8 & $0.82[0.24-2.78]$ & $0.96[0.25-3.70]$ \\
\hline \multicolumn{9}{|c|}{ Thoughts of the future: When I am 18 I will.... } \\
\hline Maybe be pregnant/got someone pregn & ant: & & $p=0.162$ & $p=0.055$ & & & $p=0.044$ & $p=0.008$ \\
\hline No & 2855 & 0.5 & 1.00 & & 2729 & 0.8 & 1.00 & \\
\hline Yes & 651 & 0.9 & $1.88[0.78-4.55]$ & $2.16[0.98-4.72]$ & 531 & 1.7 & $2.12[1.02-4.42]$ & $2.76[1.30-5.88]$ \\
\hline Be at college or university: & & & $p=0.121$ & $p=0.159$ & & & $p=0.309$ & $p=0.165$ \\
\hline No & 1829 & 0.7 & 1.00 & & 1580 & 0.7 & 1.00 & \\
\hline Yes & 1550 & 0.3 & $0.46[0.17-1.23]$ & $0.50[0.19-1.31]$ & 1603 & 1.1 & $1.40[0.73-2.69]$ & $1.66[0.81-3.41]$ \\
\hline \multicolumn{9}{|l|}{ Sexual-refusal self-efficacy: } \\
\hline Will not be able to stop somebody & & & $p=0.152$ & $p=0.171$ & & & $p=0.014$ & $p=0.022$ \\
\hline $\begin{array}{l}\text { pressuring me to have sex } \\
\text { Will be able to stop somebody }\end{array}$ & 1710 & 0.7 & 1.00 & & 1649 & 0.6 & 1.00 & \\
\hline pressuring me & 1796 & 0.4 & $0.54[0.24-1.25]$ & $0.56[0.24-1.28]$ & 1612 & 1.3 & $2.18[1.17-4.06]$ & $2.16[1.12-4.17]$ \\
\hline $\begin{array}{l}\text { It is OK/think it is OK to force } \\
\text { someone to have sex } \\
\text { It is not OK to force someone to have }\end{array}$ & 476 & 1.0 & $p=0.137$ & $p=0.437$ & 415 & 0.5 & $p=0.262$ & $p=0.273$ \\
\hline sex & 3033 & 0.5 & $0.47[0.18-1.27]$ & $0.60[0.17-2.16]$ & 2843 & 1.0 & $2.16[0.56-8.31]$ & $2.31[0.52-10.33]$ \\
\hline \multicolumn{9}{|l|}{ Condom self-efficacy: } \\
\hline Not sure will use or won't use & & & $p=0.959$ & $p=0.849$ & & & $p=0.691$ & $p=0.724$ \\
\hline condoms in the future & 1905 & 0.6 & 1.00 & & 2712 & 0.9 & 1.00 & \\
\hline Will use condoms in the future & 1600 & 0.6 & $0.97[0.36-2.64]$ & $0.91[0.36-2.31]$ & 546 & 1.1 & $1.20[0.49-2.93]$ & $1.19[0.45-3.17]$ \\
\hline $\begin{array}{l}\text { Not sure/could not tell my partner we } \\
\text { must use condoms }\end{array}$ & 1799 & 0.6 & $p=0.920$ & $p=0.989$ & 2478 & 0.9 & $p=0.491$ & $p=0.608$ \\
\hline $\begin{array}{l}\text { Will tell my partner we must use } \\
\text { condoms }\end{array}$ & 1712 & 0.6 & $1.05[0.40-2.79]$ & $1.01[0.41-2.49]$ & 779 & 1.2 & $1.32[0.60-2.90]$ & $1.24[0.55-2.80]$ \\
\hline \multicolumn{9}{|l|}{ Behaviours: } \\
\hline Never tried alcohol & 2524 & 0.6 & $p=0.457$ & $p=0.460$ & 2876 & 0.9 & $p=0.119$ & $p=0.248$ \\
\hline Have tried alcohol & 976 & 0.4 & $0.66[0.22-1.97]$ & $0.68[0.24-1.90]$ & 376 & 1.6 & $1.86[0.85-4.04]$ & $1.59[0.72-3.49]$ \\
\hline Sexual behaviour: & & & & & & & & \\
\hline Never had sex & 3034 & 0.5 & $p=0.184$ & $p=0.287$ & 3145 & 0.9 & $p=0.917$ & $p=0.801$ \\
\hline Yes have had sex & 411 & 1.0 & $2.13[0.70-6.48]$ & $1.83[0.60-5.58]$ & 94 & 1.1 & $1.12[0.14-9.05]$ & $0.70[0.04-10.95]$ \\
\hline Biomarkers for HSV-2: & & & & & & & & \\
\hline No & 3517 & 0.6 & & & 3262 & 0.9 & $p<0.001$ & $p<0.001$ \\
\hline Yes & 4 & 0.0 & na & & 8 & 25.0 & 37.17 [7.46-185.10] & $33.43[8.77-127.51]$ \\
\hline
\end{tabular}

